\title{
Respon Tanaman Padi (Oryza sativa L.) Kabir 07 Terhadap Pupuk Organik Cair Crocober Plus Khusus Kota Padang dengan Iklim Af
}

\author{
The Rice Response (Oryza sativa L.) of Kabir 07 to Liquid Organic Fertilizer \\ Crocober Plus in Padang with Af Climate
}

\author{
Jamilah $^{\text {a* }}$, Ramdan Soleh ${ }^{\mathrm{b}}$ dan Welly Herman ${ }^{\mathrm{a}}$ \\ aProgram studi Agroteknologi Universitas Tamansiswa Padang; \\ ${ }^{b}$ mahasiswa pada Prodi Agroteknologi Universitas Tamansiswa Padang \\ email; jamilah@unitas-pdg.ac.id
}

\begin{abstract}
Abstrak
Tujuan penelitian adalah mendapatkan konsentrasi terendah Pupuk organik cair Crocober Plus (POC CP) dalam menghasilkan pertumbuhan dan hasil padi (Oryza sativa L.) yang optimal sesuai dengan iklim agroklimat setempat. Percobaan dilaksanakan sejak Oktober 2016 hingga Maret 2017 di Kelurahan Lubuk Minturun, Kecamatan Koto Tangah Padang. Bahan yang dibutuhkan adalah padi Varietas Kabir, Pupuk buatan Urea, Zwavelzur Ammonia (ZA), SP-36 dan KCl, POC CP asal Fakultas Pertanian, ajir tonggak kayu, waring sungkup. Percobaan disusun dalam Rancangan Acak Lengkap, dengan 6 konsentrasi pemberian Pupuk organik Cair Crocober Plus(CP) (v/v) $\begin{array}{lllll}\text { dengan air, yaitu; } 0 \mathrm{ml} \mathrm{L} & -1 & \text { (F0); } 25 \mathrm{ml} \mathrm{L}^{-1} & \text { (F1), } 50 \mathrm{ml} \mathrm{L}^{-1} & \text { (F2), } 75 \mathrm{ml} \mathrm{L}^{-1} \quad \text { (F3), } 100 \mathrm{ml} \mathrm{L}^{-1}\end{array}$ (F4); $125 \mathrm{ml} \mathrm{L}^{-1}$ (F5), dan 3 ulangan. Bibit padi ditanam dengan jarak tanam $25 \times 25 \mathrm{~cm}$, dan ukuran plot $2 \times 2 \mathrm{~m}$. Data yang diperoleh dianalisis menggunakan analysis of variance (ANOVA) taraf nyata 5\%. Jika perlakuan berpengaruh nyata dilanjutkan dengan uji BNT taraf nyata 5\%. Parameter yang diamati antara lain; tinggi tanaman, jumlah anakan maksimum dan produktif, umur berbunga, panen, panjang malai, jumlah gabah per malai, bobot 1000 biji, berat gabah kering giling per hektar, persentase gabah hampa dan indek panen. Hasil percobaan membuktikan bahwa Pemberian $50 \mathrm{ml} \mathrm{L}^{-1}$ pupuk Organik Cair Crocober plus yang diberikan setiap 2 minggu sekali sejak 2 minggu pindah tanam hingga fase pengisian gabah mampu meningkatkan pertumbuhan dan hasil padi varietas Kabir. Hasil padi tertinggi mencapai 6,34 ton ha ${ }^{-1}$ gabah kering giling, dengan indek panen mencapai 0,53. Hasil ini masih rendah, berkisar 50\% dari kemampuan padi Kabir 07 yang ditanam di Kawasan Aceh atau Jawa Tengah.
\end{abstract}

\begin{abstract}
The study was to obtain the lowest concentration of Crocober Plus Liquid Organic Fertilizer (LOF $\mathrm{CP}$ ) to produce growth and yield of rice (Oryza sativa L.) optimally especilly for the spesific groclimate. The experiment was conducted from October 2016 to March 2017 in Lubuk Minturun, Kecamatan Koto Tangah Padang. The materials needed are variety of Kabir, Urea, Zwavelzur Ammonia (ZA), SP-36 and KCl, POC CP from the Faculty of Agriculture.. The experiments were arranged in Completely Randomized Design, with 6 concentrations of LOF CP and water ( $\mathrm{v} / \mathrm{v})$,

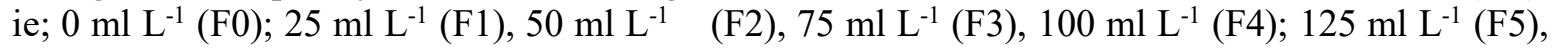
and 3 replications. Rice seedlings planted with spacing $25 \times 25 \mathrm{~cm}$, and plot size $2 \times 2 \mathrm{~m}$. The data obtained were analyzed using analysis of variance (ANOVA) 5\% real level. If the treatment had a significant effect, it was continued with HSD test of 5\% real level. Parameters observed include; Plant height, the maximum number and productive of tillers, $75 \%$ Heading. yield, panicle length, the number of spikelets per panicle, weight of 1000 spikelets, the weight of dry grain, percentage of empty spikelets and harvest index. The result proved that the giving of $50 \mathrm{ml}$ of $\mathrm{L}^{-1}$ of LOF CP as foliar application every 2 weeks since 2 weeks days after planting until grain filling phase was able
\end{abstract}


to increase growth and yield of varieties of Kabir. The highest yield of rice reached 6.34 tons ha-1, and harvest index reached 0.53 .

Kata Kunci : Chromolaena odorata, Pupuk Organik Cair Crcocober Plus, Padi Varietas Kabir (C) 2017 Jamilah Jamilah, Ben Kurniawan, Welly Herman

\section{PENDAHULUAN}

Tanaman padi varietas Kabir dipercaya mampu menghasilkan produksi gabah yang tinggi. Hal ini disebabkan karena hasil gabah permalai cukup tinggi hingga mencapai 400 bulir, demikian yang digadang-gadangkan oleh kelompok tani yang berasal dari Aceh. Namun hal ini bisa saja terjadi karena pertumbuhan padi sesuai dengan iklim di kawasan tersebut. Kelompok tani yang berasal dari Jawa menjelaskan bahwa padi tersebut tidak tahan terhadap serangan hama wereng. Beberapa kondisi dari varietas kabir yang tergolong unggul, maka padi varietas Kabir dipilih sebagai objek penelitian ini. Tanaman padi sebagaimana budidaya tanaman pangan lainnya sangat membutuhkan unsur hara untuk pertumbuhan dan hasilnya. Pada penelitian ini ingin menguji di Kota Padang, karena memang Kabir belum dikembangkan secara massal. Perlu untuk diketahui bahwa iklim kota Padang tergolong sebagai tropis. Kota Padang adalah kota dengan curah hujan yang signifikan. Bahkan di bulan terkering terdapat banyak hujan. Menurut Climate Data. Org. (2017) Köppen dan Geiger mengklasisifikasikan iklim kota Padang sebagai Af. Suhu rata-rata di Kota Padang adalah $25.9{ }^{\circ} \mathrm{C}$. Curah hujan tahunan rata-rata adalah $2866 \mathrm{~mm}$. Di antara bulan terkering dan bulan terbasah, perbedaan dalam presipitasi adalah $218 \mathrm{~mm}$. Sepanjang tahun, suhu bervariasi menurut $0.8^{\circ} \mathrm{C}$.

Penggunaan pupuk cair sudah banyak dilaporkan penggunaannyan oleh (Oosterhuis, 2009); (Jamilah \& Juniarti, 2014); (Wójcik, 2004); (Jamilah \& Juniarti, 2017). Pemberian pupuk melalui disemprotkan pada daun memebrikan beberapa keuntungan antara lain; konsentrasi pupuk digunakan dalam konsentrasi rendah, tepat sasaran dan tepat waktu; lebih praktis dan biayanya lebih murah.

Bahkan penggunaan pupuk cair mampu mengurangi penggunaan pupuk buatan hingga 25\% (Jamilah, Ediwirman, \& Ernita, 2015). Pupuk cair yang digunakan dan telah diuji pada berbagai kondisi dan waktu adalah pupuk organik cair Crocober Plus (POC CP). Pupuk tersebut dibuat dari bahan baku tanaman Chromolaena odorata (C.odorata). Tanaman ini tergolong perdu atau semak non kekacangan tergolong family asteraceae, berbentuk perdu, tahan pangkas dan batangnya berkayu (Prawiradiputra, 2007). Tanaman ini mengandung bahan alkaloid atau anti oksidan bisa diajdikan sebagai obat-obatan (Akinmoladun, Ibukun, \& Dan-Ologe, 2007); (Phan et al., 2001); (Onkaramurthy et al., 2013); (Omokhua, McGaw, Finnie, \& Van Staden, 2016). Di bidang pertanian tanaman ini palingtidakdisukai, karena penyebaran pertumbuhannya atau invasif yang luar biasa, sehingga menghabiskan ongkos usaha tani yang cukup tinggi mengendalikannya (Prawiradiputra, 2007). Di sisi lain tanaman C.odorata mengandung unsur hara $\mathrm{N}$ dan $\mathrm{K}$ yang cukup tinggi hingga melebihi 3\% (Jamilah, Munir, \& Fatimah, 2011), maka potensial dijadikan sebagai bahan utama pembuatan pupuk organik cair.

Penggunaan POC CP telah dilakukan dalam berbagai kajian dan pada lokasi yang berbeda-beda (Jamilah, Ediwirman, \& Ernita, 2014); (Jamilah \& Novita, 2016); (Jamilah et al., 2015); dengan hasil juga berbeda-beda, karena sangat ditentukan oleh jenis tanaman, lokasi dan waktu.akan tetapi POC CP juga telah dibuktikan memberikan efek yang tidak kalah dibandingkan Pupuk cair komersial seperti K-Getz, TNT dan NASA (Jamilah, Fadhila, \& Mulyani, 2017); (Jamilah, 2017). Diharapkan padi varietas Kabir memberikan respon yang baik terhadap aplikasi POC CP, sehingga diketahui konsentrasi yang tepat dalam aplikasinya di lapangan. Pada penelitian sebelumnya yang telah dibuktikan oleh (Jamilah et al., 2015); (Jamilah \& Juniarti, 
2017) bahwa hasil padi meningkat setelah aplikasi POC CP hingga $200 \mathrm{ml} \mathrm{L}^{-1}$ setiap 2 minggu sekali hingga tanaman padi pengisian gabah. Masih perlu diketahui jika konsentrasi POC CP diturunkan konsentrasinya hingga 25 $\mathrm{ml} \mathrm{L}^{-1}$. Penelitian ini bertujuan untuk mendapatkan konsentrasi terendah POC CP dalam menghasilkan pertumbuhan dan hasil padi Kabir (Oryza sativa L.) yang optimal di Kota Padang dengan iklim Af.

\section{BAHAN DAN METODA}

Penelitian ini telah dilaksanakan di lahan sawah Koto Panjang Ikua Koto. Kec. Koto Tangah di Kota Padang yang dari Desember 2016 sampai April 2017 dengan jenis tanah Ultisol. Bahan yang dibutuhkan dalam percobaan ini adalah; POC CP, benih Padi Kabir, pupuk buatan sebagai pupuk dasar yang diberikan $75 \%$ takaran rekomendasi. Takaran rekomendasi antara lain $200 \mathrm{~kg} \mathrm{ha}^{-1}$ Urea, $150 \mathrm{~kg} \mathrm{ha}^{-1}$ SP36, $100 \mathrm{~kg}$ $\mathrm{ha}^{-1} \mathrm{KCl}$ sebagai pupuk dasar, waring, kayu tonggak. Alat yang dibutuhkan antara lain cangkul, ember, saringan, sprayer, parang, pisau, meteran, alat tulis, gunting tanaman. Jenis POC CP diperoleh dari Fakultas Pertanian Univ. Tamansiswa Padang dan sudah mendapatkan hak paten sederhana dari Kemenkumham (Padang, 2016).

Percobaan ini dilakukan dengan menggunakan Rancangan Acak Lengkap (RAL) dengan 6 perlakuan pemberian POC CP, yaitu; $0 \mathrm{ml}$ (F0); $25 \mathrm{ml} \mathrm{L}^{-1}$ (F1), $50 \mathrm{ml} \mathrm{L}^{-}$ ${ }^{1}$ (F2), $\quad 75 \mathrm{ml} \mathrm{L}^{-1}$ (F3), $100 \mathrm{ml} \mathrm{L}^{-1}$ (F4) dan $125 \mathrm{ml} \mathrm{L}^{-1}$ (F5), ulangan sebanyak 3 kali, total plot 18 buah. Ukuran plot $2 \times 2 \mathrm{~m}$ dengan jarak tanam $25 \times 25 \mathrm{~cm}$, ditanam 2 anakan per titik tanam. Data disidik ragam menggunakan ANOVA taraf nyata 5\%, jika perlakuan berpengaruh nyata maka dilanjutkan dengan uji BNT taraf nyata $5 \%$.

Benih padi disemai pada persemaian setelah berumur 2 minggu dipersemaian maka dipindahtanamkan ke lapangan. Tanaman padi dipupuk 1 minggu setelah pindah tanam, dengan memberikan keseluruhan pupuk SP36 dan $\mathrm{KCl}$, sedangan Urea diberikan 50\% saat ini dan sisanya setelah 30 hari kemudian. Air dipertahankan menggenangi tanaman hingga 5 $\mathrm{cm}$ dari permukaan tanah, setelah mencapai fase pengisian gabah, bertahap air dikurangi untuk mempercepat proses pematangan. Pemberian perlakuan POC CP dilakukan mulai 1 minggu padi setelah tanam dan selanjutnya tiap 2 minggu sekali dan dihentikan saat tanaman sudah memasuki pengisian gabah. Parameter yang diamati antara lain; tinggi tanaman, jumlah anakan maksimum, anakan produktif, umur berbunga, umur panen, panjang malai, persentase gabah hampa, jumlah gabah permalai, bobot 1000 butir gabah, berat gabah kering giling dan indek panen. Penetapan persentase gabah hampa dilakukan sebagai berikut: jumlah gabah hampa per malai/(jumlah gabah per malai) x $100 \%$. Indeks panen dilakukan dengan mengambil sampel gabah dan jerami per rumpun kemudian dikeringovenkan pada suhu $70^{\circ} \mathrm{C}$ selama 3 hari atau hingga berat konstan. Kemudian dengan menggunakan rumus sebagai berikut: berat gabah kering tetap/(berat gabah kering tetap+ berat jerami kering tetap).

\section{HASIL DAN PEMBAHASAN}

Pengaruh konsentrasi dan interval pemberian $\mathrm{POC} \mathrm{CP}$ berpengaruh nyata terhadap anakan maksimum, dan sebaliknya tidak nyata terhadap tinggi tanaman, anakan produktif, umur berbunga dan panen padi Kabir, Tabel 1 dan Gambar 1 dan $2 . \quad$ Tinggi tanaman padi sangat dipengaruhi oleh konsentrasi POC CP. Pemberian $50 \mathrm{ml} \mathrm{L}^{-1}$ POC CP mampu meningkatkan pertambahan tinggi tanaman padi, kemudian ditingkatkan lagi konsentrasinya hingga $125 \mathrm{ml} \mathrm{L}^{-1}$ tinggi tanaman tidak meningkat secara nyata. Berarti POC CP yang diberikan sebanyak 50 $\mathrm{ml} \quad \mathrm{L}^{-1}$ sudah cukup optimal dalam meningkatkan pertambahan tinggi tanaman, anakan maksimum dan anakan produktif. Bahkan anakan produktif menurun jika konsentrasi POC CP ditingkatkan lagi melebihi $50 \mathrm{ml} \mathrm{L}^{-1}$. Umur berbunga dan panen padi tidak dipengaruhi oleh konsentrasi pemberian POC CP. Sifat genetik padi Kabir sangat dominan mempengaruhi munculnya bunga $75 \%$ dan usia 
panen padi. padi Kabir tergolong tanaman padi genjah.

Secara umum tidak ada perbedaan masing-masing pemberian interval dan konsentrasi POC CP terhadap jumlah anakan produktif, umur berbunga dan umur panen. Hal ini membuktikan bahwa beberapa komponen pertumbuhan tersebut lebih dominan dipengaruhi fakor genetic dibandingkan efek lingkungan khususnya pemupukan organic cair. Namun demikian efek POC terlihat nyata terhadap jumlah anakan maksimum. Anakan maksimum tertinggi diperoleh pada perlakuan $25 \mathrm{ml} \mathrm{L}^{-1}$ dan tidak berbeda nyata dibandingkan dengan pemberian POC sebanyak $50 \mathrm{ml} \mathrm{L}^{-1}$.
Anakan maksimum tertinggi anakan. Anakan maksimum belum bisa menjadi ketentuan untuk menghasilkan produksi gabah padi yang tinggi. Jika ditinjau jumlah anakan produktif terlihat bahwa anakan maksimum yang tinggi belum mampu menghasilkan anakan produktif yang tinggi juga. Jumlah anakan ini juga hampir sama terbentuk dibandingkan beras putih Pandan Wangi maupun Cisokan (Jamilah \& Helmawati, 2015). Jumlah anakan Jileteng berkisar 24- 31 anakan lebih tinggi dibandingkan jumlah anakan padi hitam Toraja (Cristanti \& Arisoesilaningsih, 2013) yaitu sebanyak 16 20 anakan.

Tabel 1. Pengaruh kombinasi interval dan konsentrasi POC CP terhadap komponen pertumbuhan vegetative dan umur bunga serta panen tanaman padi Kabir

\begin{tabular}{lrrccc}
\hline $\begin{array}{l}\text { Perlakuan pemberian POC } \\
\text { CP setiap 2 minggu sekali }\end{array}$ & $\begin{array}{c}\text { Tinggi } \\
\text { tanaman } \\
(\mathrm{cm})\end{array}$ & $\begin{array}{c}\text { Jumlah } \\
\text { Anakan } \\
\text { maksimum }\end{array}$ & $\begin{array}{c}\text { Jumlah } \\
\text { Anakan } \\
\text { produktif }\end{array}$ & $\begin{array}{c}\text { Umur } \\
\text { berbunga } \\
75 \% \text { (hari) }\end{array}$ & $\begin{array}{c}\text { Umur } \\
\text { panen } \\
\text { (hari) }\end{array}$ \\
\hline F1 $\left(0 \mathrm{ml} \mathrm{L}^{-1}\right)$ & $95,00 \mathrm{~b}$ & $32,33 \mathrm{a}$ & 22,00 & 80,00 & 117,00 \\
F2 $\left(25 \mathrm{ml} \mathrm{L}^{-1}\right)$ & $96,33 \mathrm{~b}$ & $30,83 \mathrm{a}$ & 22,00 & 78,67 & 115,67 \\
F3 $\left(50 \mathrm{ml} \mathrm{L}^{-1}\right)$ & $100,67 \mathrm{a}$ & $29,67 \mathrm{ab}$ & 23,33 & 80,33 & 117,00 \\
F4 $\left(75 \mathrm{ml} \mathrm{L}^{-1}\right)$ & $101,50 \mathrm{a}$ & $30,50 \mathrm{a}$ & 21,67 & 80,33 & 117,33 \\
F5 $\left(100 \mathrm{ml} \mathrm{L}^{-1}\right)$ & $100,67 \mathrm{a}$ & $27,67 \mathrm{~b}$ & 19,83 & 79,00 & 117,00 \\
F6 $\left(125 \mathrm{ml} \mathrm{L}^{-1}\right)$ & $99,80 \mathrm{a}$ & $28,20 \mathrm{~b}$ & 20,80 & 79,30 & 116,30 \\
\hline KK & 2,24 & 4,72 & 13,30 & 3,95 & 2,55 \\
\hline
\end{tabular}

Angka yang diikuti huruf kecil yang sama pada kolom yang sama berbeda tidak nyata menurut BNT taraf nyata $5 \%$

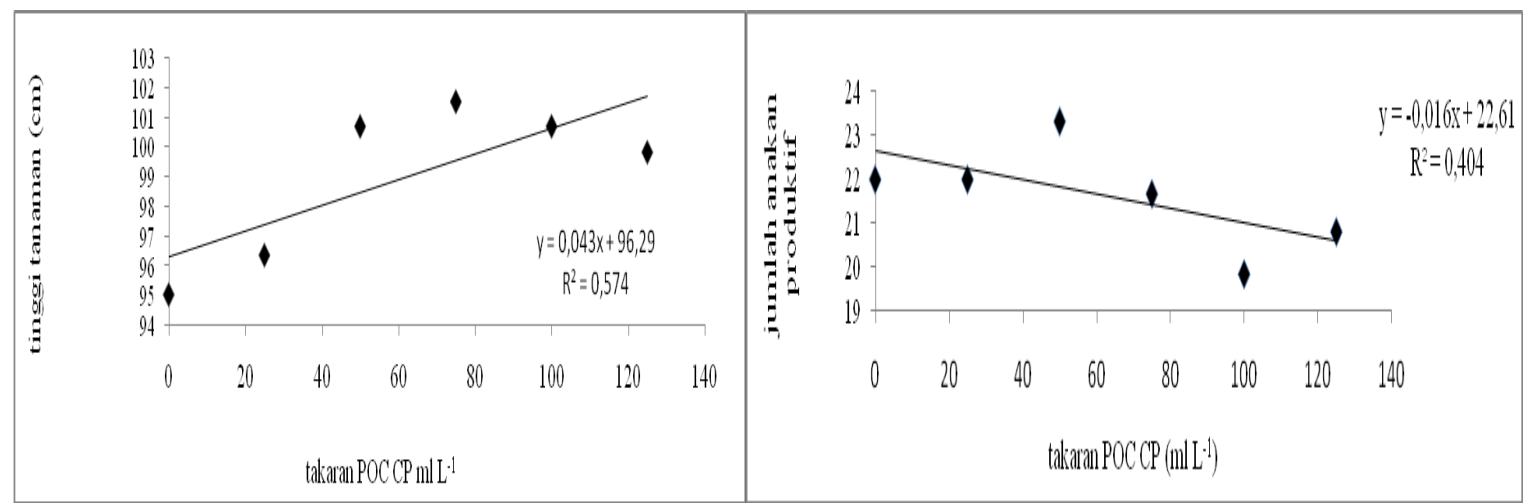

Gambar 1. Grafik hubungan antara konsentrasi POC CP terhadap tinggi tanaman dan jumlah anakan produktif tanaman padi. 


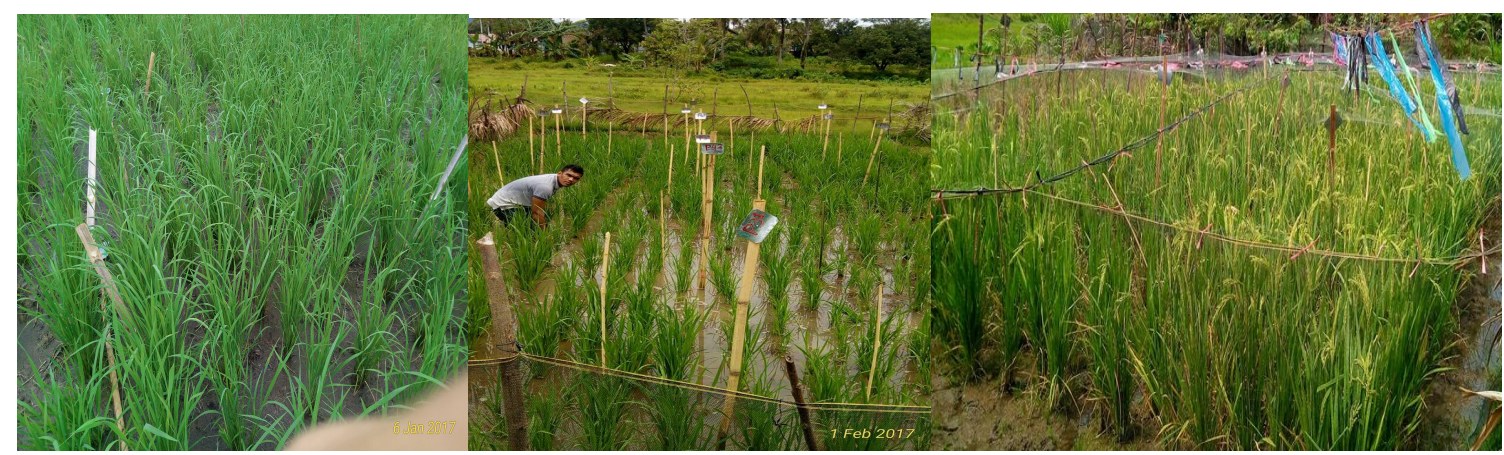

Gambar 2. Tanaman padi saat 2 mst hingga mencapai 755 pembungaan.

Tabel 2. Pengaruh konsentrasi POC CP terhadap komponen hasil tanaman padi Kabir

\begin{tabular}{|c|c|c|c|c|c|c|c|}
\hline $\begin{array}{l}\text { Perlakuan } \\
\text { pemberian POC } \\
\text { CP setiap } 2 \\
\text { minggu sekali }\end{array}$ & $\begin{array}{l}\text { Panjang malai } \\
(\mathrm{cm})\end{array}$ & $\begin{array}{l}\text { Gabah } \\
\text { Hampa } \\
(\%)\end{array}$ & $\begin{array}{l}\text { Jumlah } \\
\text { gabah per } \\
\text { malai }\end{array}$ & $\begin{array}{l}\text { Berat } \\
1000 \\
\text { biji } \\
(\mathrm{g})\end{array}$ & $\begin{array}{l}\text { Berat } \\
\text { GKG } \\
\left(\mathrm{Mg} \mathrm{ha}^{-}\right.\end{array}$ & & Indek Panen \\
\hline $\mathrm{F} 1\left(0 \mathrm{ml} \mathrm{L}{ }^{-1}\right)$ & 26,83 & $18,22 \mathrm{~b}$ & 212,00 & 31,95 & 3,99 & $\mathrm{c}$ & 0,37 \\
\hline $\mathrm{F} 2\left(25 \mathrm{ml} \mathrm{L}^{-1}\right)$ & 27,50 & $14,11 \mathrm{a}$ & 241,50 & 32,28 & 5,34 & b & 0,42 \\
\hline $\mathrm{F} 3\left(50 \mathrm{ml} \mathrm{L}^{-1}\right)$ & 26,17 & $11,83 \mathrm{a}$ & 231,00 & 32,37 & 6,34 & $\mathrm{a}$ & 0,53 \\
\hline $\mathrm{F} 4\left(75 \mathrm{ml} \mathrm{L}^{-1}\right)$ & 30,50 & $10,05 \mathrm{a}$ & 269,33 & 32,38 & 6,15 & $\mathrm{a}$ & 0,46 \\
\hline $\mathrm{F} 5\left(100 \mathrm{ml} \mathrm{L}^{-1}\right)$ & 28,83 & $10,20 \mathrm{a}$ & 254,83 & 30,61 & 5,15 & $\mathrm{~b}$ & 0,45 \\
\hline $\mathrm{F} 6\left(125 \mathrm{ml} \mathrm{L}^{-1}\right)$ & $29,30 \quad \mathrm{a}$ & $12,26 \mathrm{a}$ & 257,70 & 30,00 & 3,73 & $\mathrm{c}$ & 0,26 \\
\hline $\mathrm{KK}$ & 3,50 & 18,33 & 13,79 & 6,46 & 17,73 & & 16,75 \\
\hline
\end{tabular}

Angka-angka yang diikuti oleh huruf kecil yang sama pada kolom yang sama berbeda tidak nyata menurut BNT taraf nyata $5 \%$.

Tanaman padi Kabir yang diaplikasikan dengan berbagai konsentrasi POC CP setiap 2 minggu sekali memberikan respon yang berbeda-beda terhadap parameter panjang malai, gabah hampa, jumlah gabah per malai, bobot 1000 biji, bobot gabah kering giling hingga indeks panen, disajikan pada Tabel 2 dan Gambar 3, 4 dan 5. Semakin tinggi konsentrasi POC CP, maka semakin panjang malai yang terbentuk. Hal ini membuktikan bahwa malai terbentuk akibat nutrisi yang diberikan semakin banyak.

Gabah hampa yang dihasilkan tertinggi ditemui pada perlakuan kontrol atau yang tidak diberi POC CP. Semua tanaman yang diberi POC CP menghasilkan penurunan kehampaan pada gabah padi Kabir. Dapat dilihat bahwa tidak ada perbedaan yang nyata antar takara POC CP terhadap pembentukan gabah hampa padi. Artinya POC CP memiliki peranan dalam pengisian pati dalam gabah. Hal ini disebabkan bahwa nutrisi yang berasal dari
POC CP sangat penting pada metabolisme tanaman, sehingga pengisian gabah menjadi lebih sempurna. Pembentukan gabah serta pengisian gabah sangat ditentukan oleh ketersediaan hara yang cukup pada tanaman tersebut. Semakin kurang hara yang mampu diserap oleh tanaman, maka semakin kurang pati yang bisa diisi dalam bulir gabah padi. jumlah gabah tersebut secara umum sangat ditentukan oleh genetis tanaman. Tanaman padi Kabir memiliki jumlah gabah tergolong tinggi dibandingkan jenis padi lainnya seperti Cisokan, Pandan Wangi, Cempo merah maupun padi Jileteng (Jamilah, 2017); (Jamilah et al., 2015) berkisar antara $170-230$.

Jika dibandingkan dengan beberapa laporan yang berasal dari Daerah Aceh dan Jawa Tengah membutikan bahwa padi Kabir 07 mampu mencapai tinggi $170 \mathrm{~cm}$, dengan usia $115 \mathrm{hst}$, panjang malai $25-30 \mathrm{~cm}$, jumlah anakan 20 - 30. Jumlah bulir berkisar $500-$ 700 bulir, rerata gabah kering panen 
mencapai 12-14 Mg ha ${ }^{-1}$. Penting diketahui iklim Aceh menurut Climate-Data. Org (2017) sebagai berikut; Aceh adalah kota dengan curah hujan yang signifikan. Bahkan di bulan terkering terdapat banyak hujan. Klasifikasi iklim Köppen-Geiger adalah Af. Suhu rata-rata di Aceh adalah $23.3{ }^{\circ} \mathrm{C}$. Suhu adalah tertinggi rata-rata pada April, di sekitar $23.7^{\circ} \mathrm{C}$. Januari adalah bulan terdingin, dengan suhu rata-rata $23.0^{\circ} \mathrm{C}$. . Curah hujan di sini rata-rata 2785 $\mathrm{mm}$. Sedangkan klasififikasi iklim Jawa Tengah Khususnya Blora tempat dikembangkannya Kabir 07 tergolong, di musim penghujan dan kemarau. Jumlah curah hujan tertinggi terdapat di Kecamatan Jati dan terendah di Kecamatan Jepon. Musim kemarau terjadi bulan Mei/Juni sampai September/Oktober. Musim hujan mulai bulan Oktober-Mei. Menurut Oldeman et al. (1978), Kabupaten Blora termasuk zona C3 dan D3 yang dicirikan bulan kering 4-6 bulan dan bulan basah 4-5 bulan. Sedangkan Kecamatan Kunduran termasuk dalam zona C3 (Badan Litbang Pertanian, 2004). Perhitungan neraca air dari beberapa stasiun di Kabupaten Blora menunjukkan bahwa daerah utara Kabupaten Blora, termasuk Kecamatan Kunduran mempunyai rejim kelembaban tanah ustik, defisit (185- $265 \mathrm{~mm}$ ) terjadi selama 5 sampai 6 bulan yang terjadi pada bulan Mei sampai Oktober. Surplus terjadi selama tiga bulan (Januari sampai Maret) sebesar $258 \mathrm{~mm}$ (Badan Litbang Pertanian, 2004). Data curah hujan Kecamatan Kunduran peride 2006- 2010 yang diperoleh dari UPTD Pertanian Kecamatan Kunduran (Suryani, 2014).

Bobot 1000 biji gabah padi kabir juga lebih tinggi dibandingkan jenis padi yang lainnya. Ukuran padi kabir tergolong besar sehingga menimbulkan berat yang lebih tinggi. Akan tetapi bobot biji tersebut tidak dipengaruh oleh konsentrasi pemberian POC
CP. Jumlah gabah per malai juga tidak ada yang mencapai 400 bulir seperti yang sudah dilaporkan tersebut. Indek Panen padi kabir tertinggi pada perlakuan konsentrasi $50 \mathrm{ml} \mathrm{L}^{-1}$ dibadingkan dengan konsentrasi lainnya. Indek panen semakin tinggi jika bobot gabah semakin besar dan jerami semakin rendah. Hal ini menunjukkan bahwa metabolisme tanaman berlangsung dengan baik, unsur hara diserap secara optimal. Unsur hara yang diberikan melalui semprotan pada bagian tajuk tanaman padi, memberi kesempatan unsur tersebut berdiffusi melintasi kutikula maupun stomata daun. Pupuk berdiffusi melintasi lapisan wax dan kutin. Kutin adalah suatu polimer yang dibangun oleh asam lemak hidroksi dengan rantai $\mathrm{C} 18,1$ dan $\mathrm{C} 16,0$ dan karena adanya grup hidroksil bersifat hemi hidrofilik. Wax adalah campuran molekul hidrofobik seperti asam lemak rantai sangat panjang, hidrokarbon, ester dan alkohol (Pandey, Krishnapriya, \& Bindraban, 2013); (Shahid et al., 2016).

Wax tersusun berada di atas lapisan cutin pada epidermis daun, yang bersifat menghalangi cairan berdiffusi ke dalam jaringan daun, akan tetapi cutin bersifat semi meloloskan cairan yang berdiffusi. Oleh sebab itu pupuk cair yang diaplikasikan harus memiliki kemampuan sifat merekat dan memiliki permukaan yang luas agar unsur hara dari pupuk cair mampu berdiffusi ke dalam jaringan daun (Mengel, 1995); (Mengel \& Kirkby, 2001). Pada Gambar 2, menunjukkan bahwa panjang malai terpanjang dan gabah hampa terendah diperoleh dari hasil perlakuan $75 \mathrm{ml} \mathrm{L}^{-1}$ POC CP akan tetapi tidak berbeda nyata dengan perlakuan $50 \mathrm{ml} \mathrm{L}^{-1}$ (Tabel 2). Namun bobot gabah kering tertinggi dan indek panen tertinggi diperoleh dari perlakuan pemberian $50 \mathrm{ml} \mathrm{L}^{-1}$ (Gambar 3 dan Tabel 2). 

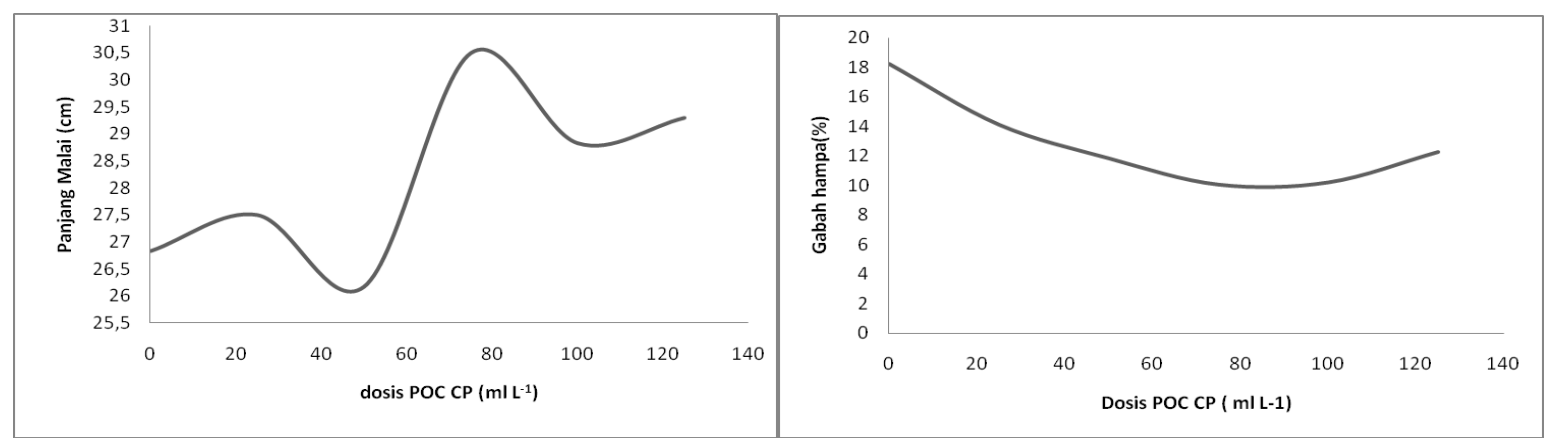

Gambar 3. Grafik hubungan konsentrasi POC CP terhadap panjang malai dan gabah hampa padi

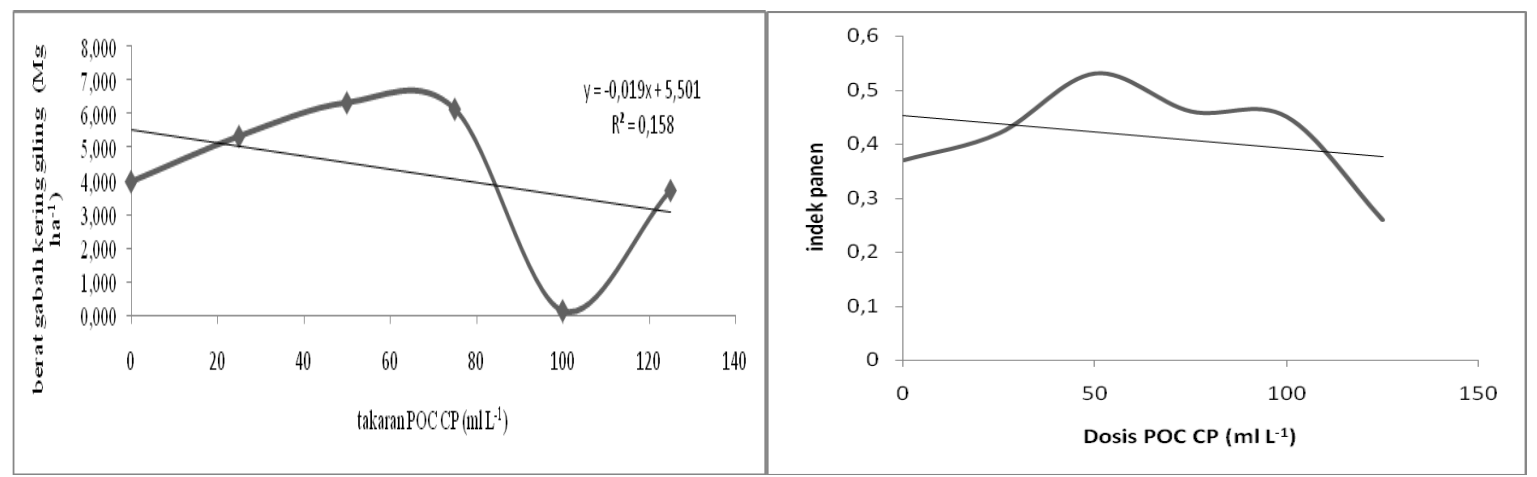

Gambar 4. Grafik hubungan konsentrasi POC CP terhadap bobot gabah kering giling dan indek panen padi

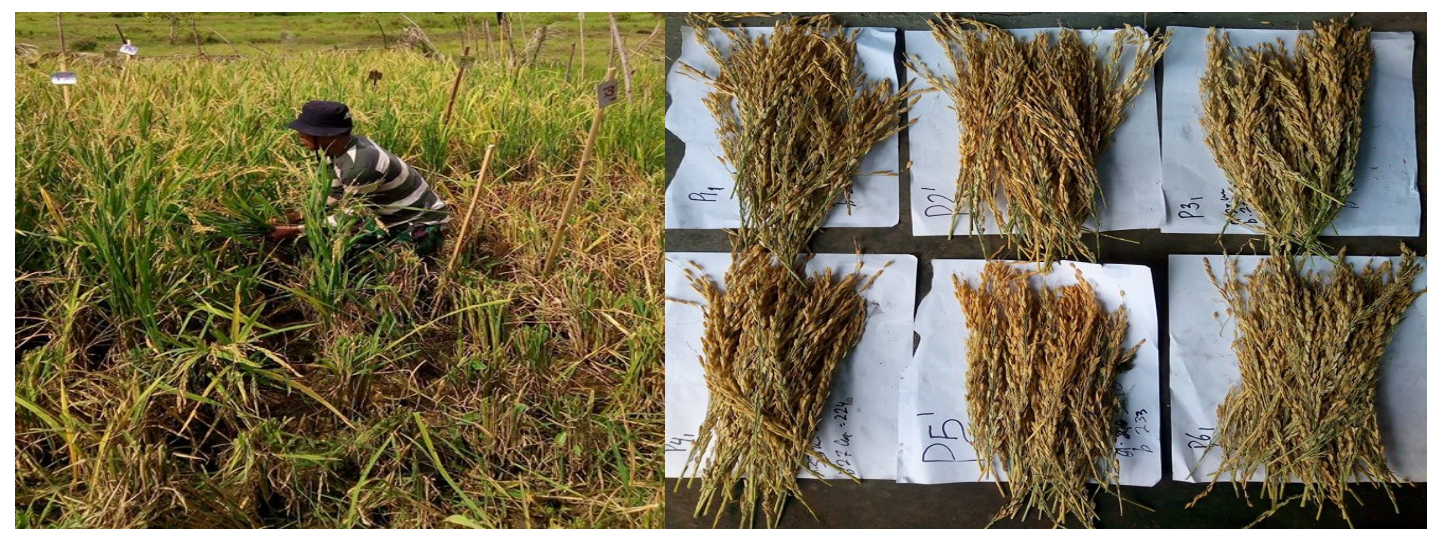

Gambar 5. Saat panen padi Kabir 07, masing-masing gabah yang dihasilkan berdasarkan perlakuan mulai dari P1, P2, P3, P4, P5 dan P6d

Aplikasi pupuk melalui daun lebih berhasil jika konsentrasi yang diberikan semakin rendah. hal ini berhubungan dengan sifat kutikula yang melindungi lapisan epidermis daun. Oleh sebab itu pemberian pupuk melalui daun lebih mengutamakan nutrisi yang mikro dibandingkan nutrisi makro.
Hal ini disebabkan nutrisi makro lebih banyak dibutuhkan oleh tanaman dalam pertumbuhannya, sehingga aplikasi melalui daun menjadi tidak efektif. Menurut (Mengel \& Kirkby, 2001) pemberian pupuk cair lebih menguntungkan bagi menyediakan unsur hara mikro dibandingkan unsur hara makro. 
Kecuali unsur hara $\mathrm{N}$ yang berasal dari urea, jika diaplikasikan melalui daun memiliki permeabilitas yang tinggi, sehingga mudah berdiffusi melalui daun. Selanjutnya aplikasi pupuk cair melalui daun efektif jika perkaran tanaman sudah lebih dalam sehingga sulit menerima pupuk yang diberikan dangkal di permukaan tanah. Pemberian pupuk cair juga efektif jika ketersediaan unsur hara di dalam tanah sangat rendah (Gutiérrez-gamboa, Garde-cerdán, Portu, Moreno-simunovic, \& Martínez-gil, 2017).

Demikian halnya jika takaran POC CP ditingkatkan lebih dari $75 \mathrm{ml} \mathrm{L}^{-1}$, terjadi penurunan berat gabah kering secara nyata. Betapa pentingnya memperhatikan konsentrasi POC CP jika ingin memberikannya ke tanaman yang disemprotkan melalui daun. Walaupun pupuk ini tergolong pupuk cair organik, yang berasal dari bahan organik murni, ternyata pemberian dalam konsentrasi tinggi akan menurunkan hasil juga. Jika dibandingkan dengan kondisi lapangan yang tanamannya diberi pupuk namun berasal dari pupuk kimia an organik, memiliki trend yang demikian. Kecenderungan menurun produksi disebabkan pupuk tersebut tidak lagi sebagai sumber hara untuk memenuhi kebutuhan nutrisi tanaman, akan tetapi sebagi unsur hara yang terkandung di dalam pupuk tersebut sudah menjadi racun atau bahan yang mengganggu metabolisme tanaman.

\section{KESIMPULAN}

Pemberian $50 \mathrm{ml} \mathrm{L} \mathrm{L}^{-1}$ pupuk Organik Cair Crocober plus yang diberikan setiap 2 minggu sekali sejak 2 minggu pindah tanam hingga fase pengisian gabah mampu meningkatkan pertumbuhan dan hasil padi varietas Kabir 07. Hasil padi tertinggi mencapai 6,34 ton $\mathrm{ha}^{-1}$ gabah kering giling, dengan indek panen mencapai 0,53. Akan tetapi Kota Padang dengan Iklim Af hanya mencapai $50 \%$ lebih rendah hasilnya dibandingkan dengan di Aceh ataupun Jawa Tengah.

Implikasinya adalah memberikan informasi yang tepat dalam merekomendasikan POC CP di lapangan khususnya untuk memupuk tanaman padi sawah agar mencapai pertumbuhan dan hasil padi sawah secara optimal. Aplikasi POC CP merupakan rekomendasi pemupukan yang murni berasal dari bahan organik sesuai mendukung lingkungan sehat dan mampu mengurangi $25 \%$ penggunaan pupuk buatan.

\section{UCAPAN TERIMAKASIH}

Ucapan terima kasih disampaikan kepada Kemenristek Dikti, karena telah mendanai sebagian kegiatan ini melalui skim Hibah Strategis Nasional nomor kontrak; 005/KONTRA-PENELITIAN/K10/KM/2017, tanggal 1 Desember 2016.

\section{DAFTAR PUSTAKA}

Akinmoladun, A. C., Ibukun, E. O., \& DanOloge, I. A. (2007). Phytochemical constituents and antioxidant properties of extracts from the leaves of Chromolaena odorata. Scientific Research and Essays, 2(6), 191-194.

Bambang R. Prawiradiputra. (2007). Ki Rinyuh (Chromolaena odorata (L) R.M. King Dan H. Robinson): Gulma Padang Rumput Yang Merugikan. Wartazoa, 17(1), 46-52.

Cristanti, L. D., \& Arisoesilaningsih, E. (2013). Pertumbuhan padi Kabir dan serangan beberapa herbivor di sawah padi organik kecamatan kepanjen. Jurnal Biotropika, 1 No. 5, 221-225.

Climate Data.Org. 2017. Iklim Kota Padang. https://id.climatedata.org/location/578078/.

Climate-Data Org. 2017. Iklim Aceh. https://id.climatedata.org/location/587318/

Gutiérrez-gamboa, G., Garde-cerdán, T., Portu, J., Moreno-simunovic, Y., \& Martínezgil, A. M. (2017). Foliar nitroen application in Cabernet Sauvignon vines: Effect on wine flavonoid and amino acid 
content. Food Research International. http://doi.org/10.

1016/j.foodres.2017.03.025

Jamilah. (2017). Pengaruh Pupuk Organik Cair Asal C.odorata Terhadap Serapan Hara Kalium Dan Hasil Padi Ladang. Jurnal Bibiet, ISSN 2502-0951, 1(1), 17-26. http://doi.org/http://dx.doi.org/10.22216/ jbbt.v1i1.258

Jamilah, Ediwirman, \& Ernita, M. (2014). Produk Pupuk Organik Cair Asal Sabut Kelapa Dan Gulma C.Odorata Yang Difermentasi Dengan Mikroorganisme Lokal (Mol) Untuk Meningkatkan Serapan Hara Kalium Dan Hasil Padi Ladang, Tahun ke 2. Laporan HB Tahun ke 2 Universitas Tamansiswa. Padang.

Jamilah, Ediwirman, \& Ernita, M. (2015). the Effect of Fermented Liquid Organic FerTilizer and Potassium for Nutrient Uptake and Yield of Rice At Tropical Upland. J. Environ.Res.Develop., 9(04), $1-6$.

Jamilah, Fadhila, R., \& Mulyani, S. (2017). Farm Analysis of Rice Crop Trimmed Periodically in the Tropical Wet. In T. Yuwono, T. Purwaningsih, \& Maulana (Eds.), International Conference on Social, Humanities and Government Science ISBN 978-602607620-5 (pp. 202-207). Palembang: Tamansiswa Palembang University.

Jamilah, \& Helmawati. (2015). Kajian Analisis Usaha Tani Integrasi Padi Sawah dan Pakan Ternak Ruminansia Menunjang Kedaulatan Pangan dan Daging Dalam Menghadapi Masyarakat Ekonomi Asean 2015. In Seminar Nasional Kesiapan Indonesia dalam Menghadapi Pasar Bebas Asean Melalui Penguatan Implementasi Corporate Governance yang Sehat (Vol. 3, pp. 254-266). Padang: Perpustakaan Nasional RI.
Jamilah, \& Juniarti. (2014). Test of Liquid Organic Fertilizer Originated C.odorata and Coconut Fiber With Various Composition by Length Fermentation. Journal of Environmental Research and Development, $9(01)$.

Jamilah, \& Juniarti. (2017). Chromolaena odorata Compost Affected Soil Chemical and Rice Crop (Oryza sativa L.). Agrotechnology, 06(01), 1-6. http://doi.org/10.4172/21689881.1000155

Jamilah, Munir, R., \& Fatimah. (2011). Pengayaan Pupuk Bioorganik C. Odorata Dengan Tepung Tulang Dan Pf Pts Multi Lokasi Bidang Penelitian: TANAMAN PANGAN Oleh Ketua Peneliti Anggota ( BPTP) UNITAS: Dr. Ir . JAMILAH , MP ( kesuburan Tanah) : Ir . Rafli Munir, MS Penma ( Tanaman pangan. Padang.

Jamilah, \& Novita, E. (2016). Pengaruh Pupuk Organik Cair Crocober Terhadap Tanaman Bawang Merah (Allium ascalonicum L.). Jurnal Ipteks Terapan, 1.

Mengel, D. (1995). Roots , Growth and Nutrient Uptake. AGRY-95-08, 08(Figure 2), 2-8.

Mengel, K., \& Kirkby. (2001). Principles of plant nutrition. 5th edn. (5th ed.). Kluwer Academic Publishers. http://doi.org/10.1093/aob/mch063

Omokhua, A. G., McGaw, L. J., Finnie, J. F., \& Van Staden, J. (2016). Chromolaena odorata (L.) R.M. King \& H. Rob. (Asteraceae) in sub-Saharan Africa: A synthesis and review of its medicinal potential. Journal of Ethnopharmacology, 183, 112-122. http://doi.org/10.1016/j.jep.2015.04.057

Onkaramurthy, M., Veerapur, V. P., 
Thippeswamy, B. S., Madhusudana Reddy, T. N., Rayappa, H., \& Badami, S. (2013). Anti-diabetic and anti-cataract effects of Chromolaena odorata Linn.; In streptozotocin-induced diabetic rats. Journal of Ethnopharmacology, 145(1), 363-372.

http://doi.org/10.1016/j.jep.2012.11.023

Oosterhuis, D. (2009). Foliar fertilization: mechanisms and magnitude of nutrient uptake. Proceedings of the Fluid Forum, 15-17. Padang, U. T. (2016). paten_1 (1).pdf.

Pandey, R., Krishnapriya, V., \& Bindraban, P. S. (2013). Biochemical Nutrient Pathways in Plants Applied as Foliar Spray: Phosphorus and Iron Biochemical Nutrient Pathways in Plants Applied as Foliar Spray: Phosphorus and Iron. Washington D.C, USA.

Phan, T. T., Wang, L., See, P., Grayer, R. J., Chan, S. Y., \& Lee, S. T. (2001). Phenolic compounds of Chromolaena odorata protect cultured skin cells from oxidative damage: implication for cutaneous wound healing. Biological \& Pharmaceutical Bulletin, 24(12), 13731379.

http://doi.org/10.1248/bpb.24.1373

Shahid, M., Dumat, C., Khalid, S., Schreck, E., Xiong, T., \& Niazi, N. K. (2016). Foliar heavy metal uptake, toxicity and detoxification in plants: A comparison of foliar and root metal uptake. Journal of Hazardous Materials. http://doi.org/ 10.1016/j.jhazmat.2016.11.063

Suryani, E. (2014). Karakteristik Tanah dan Kesesuaian Lahan Tanaman Tebu di Kecamatan Kunduran , Blora , Jawa Tengah. Tanah Dan Iklim, 1(37), 57-68.

Wójcik, P. (2004). Uptake of mineral nutrients from foliar fertilization. Journal of Fruit and Ornamental Plant Research, 12(Special ed.: Orchard management in sustainable fruit production), 201-218. http://doi.org/10.1021/jf062764p 